\title{
Geographical Variation of the Furanocoumarin Composition of the Fruits of Icelandic Angelica archangelica
}

\author{
Steinthor Sigurdsson ${ }^{\mathrm{a}, \mathrm{b}, *}$, Sigridur Jonsdottir ${ }^{\mathrm{b}}$, and Sigmundur Gudbjarnason ${ }^{\mathrm{a}, \mathrm{b}}$ \\ a SagaMedica, Vatnagardar 18, IS-104 Reykjavik, Iceland. E-mail: steinthor@sagamedica.is \\ b Science Institute, University of Iceland, Dunhagi 3, IS-107 Reykjavik, Iceland \\ * Author for correspondence and reprint requests \\ Z. Naturforsch. 67 c, 1-7 (2012); received April 6/November 3, 2011
}

Angelica archangelica fruits were collected from 64 locations around Iceland and analysed for furanocoumarins by high-performance liquid chromatography. The average furanocoumarin content was found to be $22.5 \mathrm{mg} / \mathrm{g}$, ranging from 14.0 to $31.6 \mathrm{mg} / \mathrm{g}$. Whereas imperatorin was the main compound in all samples, the order of other compounds was highly diverse. Considerable differences were observed between individuals from the same location and between neighbouring locations. However, strong geographical impact was observed on the composition, with isoimperatorin and bergapten being more pronounced in South Iceland, and oxypeucedanin and an unidentified compound being more pronounced in North Iceland and absent in many samples from South Iceland.

Key words: Angelica archangelica, Iceland, Imperatorin, HPLC

\section{Introduction}

Angelica archangelica has been long and widely used in folk medicine, and is one of the most respected medicinal herbs in Nordic countries, where it was cultivated during the Middle Ages and exported to other parts of Europe. A. archangelica growing in Iceland is of the subspecies $A$. archangelica ssp. litoralis (Löve, 1977). The most characteristic secondary metabolites of its fruits are essential oils and furanocoumarins (Newall et al., 1996). Furanocoumarins have various pharmacological properties depending on their respective substituent groups. Xanthotoxin and bergapten have long been used in photochemotherapy with psoralen and UV-A (PUVA), due to their photosensitizing activities. The chemical structures of the furanocoumarins most relevant in this study are shown in Fig. 1.

Imperatorin is usually considered the most abundant furanocoumarin of $A$. archangelica fruit (Newall et al., 1996). Its biological activity has been the subject of many studies, showing various effects on the inflammatory process (Ban et al., 2003; Abad et al., 2001; Wang et al., 1999), antiproliferative activity on cancer cells (Kawaii et al., 2001; Sigurdsson et al., 2004), and induction of apoptosis (Pae et al., 2002; Appendino et al., 2004). Its effect on cytochromes $\mathrm{P} 450$ has been investigated in connection with drug and xenobi- otic metabolism (Kleiner et al., 2008). It has been shown to induce vasodilation (Chiou et al., 2001; $\mathrm{He}$ et al., 2007). Imperatorin has been reported to inhibit the breakdown of the neurotransmitters acetylcholine (Kim et al., 2002; Di Giovanni et al., 2008) and $\gamma$-aminobutyric acid (GABA) (Choi et $a l ., 2005)$, to facilitate the release of the neurotransmitter glutamate (Wang et al., 2008), and to inhibit phosphodiesterases 4A and 4B (Ivey et al., 2008).

As the pharmacological properties of different furanocoumarins are diverse, knowledge of the furanocoumarin composition of raw material is highly relevant.

\section{Material and Methods}

\section{Samples and extraction}

Fruits of $A$. archangelica were collected from 64 locations between August 11 and August 21, 2008.

The fruits were usually from 20 individual plants in each location. The selected fruits had preferably reached full size but were not dry or drying. The fruits were dried at room temperature until their dry weight content had reached $90-93 \%$. They were then ground. A portion of each sample was kept at $110^{\circ} \mathrm{C}$ overnight to establish the dry weight. Thereafter the samples were extracted with $96 \%$ ethanol, approximately $70 \mathrm{mg}$ in $7 \mathrm{ml}$, at room temperature for $7 \mathrm{~d}$. They were subse- 
<smiles>COc1c2ccoc2cc2oc(=O)ccc12</smiles>

Bergapten (1)<smiles>CC(C)=CCOc1c2ccoc2cc2oc(=O)ccc12</smiles>

Isoimperatorin (3)<smiles>CC1(C)O[C@@H]1COc1c2ccoc2cc2oc(=O)ccc12</smiles>

Oxypeucedanin (5)<smiles>COc1c2occc2cc2ccc(=O)oc12</smiles>

Xanthotoxin (2)<smiles>CC(C)=CCOc1c2occc2cc2ccc(=O)oc12</smiles>

Imperatorin (4)<smiles>COc1c2ccoc2c(OCC=C(C)C)c2oc(=O)ccc12</smiles>

Phellopterin (6)

Fig. 1. Chemical structures of the analysed compounds.

quently filtered, and the furanocoumarin content was measured by high-performance liquid chromatography (HPLC). Each sample was extracted and analysed in triplicate.

\section{Quantitative furanocoumarin analysis by HPLC}

Samples were diluted to a concentration of $1-100 \mu \mathrm{g} / \mathrm{ml}$ of individual compounds. A HP1100 (Hewlett Packard, Palo Alto, CA, USA) instrument with a quaternary pump and a diode array detector was used. The stationary phase of the column (50 x 4.6 mm I.D.) was Zorbax SBC18 with a particle size of $1.8 \mu \mathrm{m}$. Gradient elution was as follows: $0-7 \mathrm{~min}$ from $60-95 \%$ (v/v) aqueous methanol, detection at 305 and $309 \mathrm{~nm}$ at room temperature, with a flow rate of $1.0 \mathrm{ml} /$ min. Each sample was diluted appropriately (to a maximum of ca. $100 \mu \mathrm{g} / \mathrm{ml}$ of individual furano-

coumarin) before measurement, and its signal at 305 and $309 \mathrm{~nm}$ was monitored and compared with standard curves of xanthotoxin with known concentrations. In the case of the other furanocoumarins, the same relationship of signal to concentration was assumed as for xanthotoxin and corrected using the respective extinction coefficients at their maxima at about $300 \mathrm{~nm}$ (Lee and Soine, 1969). In the cases of unidentified furanocoumarins (identified as such by their UV spectra), molecular weight and extinction coefficients were assumed as the average of those of the known compounds. A representative chromatogram is shown in Fig. 2.

\section{Identification of furanocoumarins}

In the case of xanthotoxin and bergapten, standards were purchased (Sigma, St. Louis, MO, USA). Imperatorin, isoimperatorin, oxypeucedanin, and prangenin were isolated from $A$. archangelica fruits, and identified using ${ }^{1} \mathrm{H}$ NMR spectroscopy and, in the case of imperatorin and isoimperatorin, ${ }^{13} \mathrm{C}\left\{{ }^{1} \mathrm{H}\right\}$ NMR spectroscopy. The NMR spectra were recorded in $\mathrm{CDCl}_{3}$ at 297 $\mathrm{K}$ on a Bruker AC250 spectrometer (Karlsruhe, Germany) using as an internal standard the rest signal of $\mathrm{CHCl}_{3}$ at $7.26 \mathrm{ppm}$ for the ${ }^{1} \mathrm{H} \mathrm{NMR}$ spectra and the signal of $\mathrm{CDCl}_{3}$ at $77.00 \mathrm{ppm}$ for the ${ }^{13} \mathrm{C}\left\{{ }^{1} \mathrm{H}\right\}$ NMR spectra. Identification of each substance was achieved by measuring the ${ }^{1} \mathrm{H}$ NMR and the ${ }^{13} \mathrm{C}\left\{{ }^{1} \mathrm{H}\right\}$ NMR spectra followed by the DEPT-135 experiment. For the exact identifi-

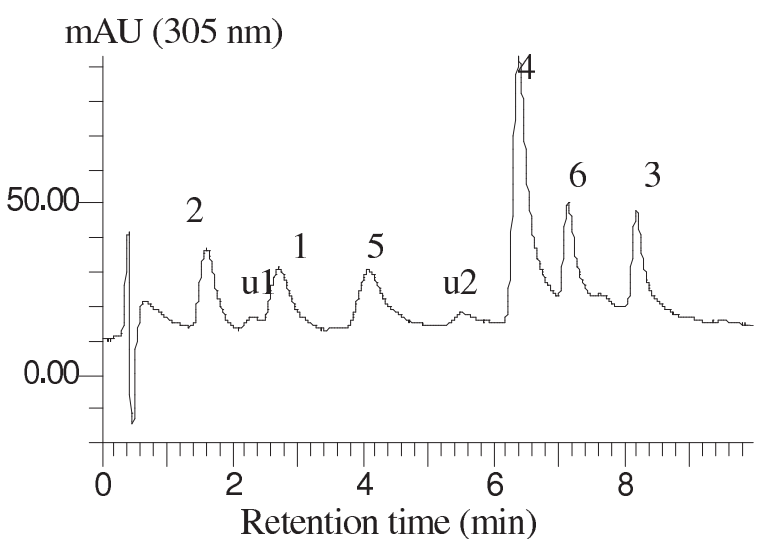

Fig. 2. Chromatogram of $A$. archangelica fruit extract: 2, xanthotoxin; u1, unidentified $1 ; 1$, bergapten; 5 , oxypeucedanin; u2, unidentified $2 ; 4$, imperatorin; 6 , assumed to be phellopterin; 3 , isoimperatorin. 
cation of the ${ }^{1} \mathrm{H}$ NMR signals, double resonance experiments were performed.

Imperatorin $\left(\mathrm{C}_{16} \mathrm{H}_{14} \mathrm{O}_{4}, M_{\mathrm{r}} 270\right):{ }^{1} \mathrm{H} \quad \mathrm{NMR}$ $\left(\mathrm{CDCl}_{3}\right): \delta=7.74(\mathrm{~d}, J=9.6 \mathrm{~Hz}, 1 \mathrm{H}, 4-\mathrm{H}), 7.67$ (d, $\left.J=2.2 \mathrm{~Hz}, 1 \mathrm{H}, 2^{\prime}-\mathrm{H}\right), 7.33(\mathrm{~s}, 1 \mathrm{H}, 5-\mathrm{H}), 6.79$ $\left(\mathrm{d}, J=2.2 \mathrm{~Hz}, 1 \mathrm{H}, 3^{\prime}-\mathrm{H}\right), 6.33(\mathrm{~d}, J=9.6 \mathrm{~Hz}, 1 \mathrm{H}$, $3-\mathrm{H}), 5.58$ (dd, $J=7.2 \mathrm{~Hz}, J=1.4 \mathrm{~Hz}, 1 \mathrm{H}, 3$ "-H), 4.97 (d, $J=7.2 \mathrm{~Hz}, 2 \mathrm{H}, 2$ "-H), 1.71 (s, 3H, 4"-H), 1.69 (s, 3H, 5"-H). $-{ }^{13} \mathrm{C}\left\{{ }^{1} \mathrm{H}\right\}$ NMR: $\delta=160.44(\mathrm{C}-$ 2), 114.51 (C-3), 144.31 (C-4), 113.13 (C-5), 125.78 (C-6), 148.48 (C-7), 131.52 (C-8), 143.69 (C-9), 116.37 (C-10), 146.53 (C-2'), 106.68 (C-3'), 70.04 (C-2"), 119.70 (C-3"), 139.6 (C-6"), 25.71 (C-4"), 18.01 (C-5").

Isoimperatorin $\left(\mathrm{C}_{16} \mathrm{H}_{14} \mathrm{O}_{4}, M_{\mathrm{r}} 270\right):{ }^{1} \mathrm{H}$ NMR $\left(\mathrm{CDCl}_{3}\right): \delta=8.13$ [dd, $J=9.8 \mathrm{~Hz}, J=0.7 \mathrm{~Hz}$ (long range), $1 \mathrm{H}, 4-\mathrm{H}], 7.57\left(\mathrm{~d}, J=2.4 \mathrm{~Hz}, 1 \mathrm{H}, 2^{\prime}-\mathrm{H}\right)$, $7.11(\mathrm{dd}, J=0.8 \mathrm{~Hz}, J=0.9 \mathrm{~Hz}, 1 \mathrm{H}, 8-\mathrm{H}), 6.94$ $\left(\mathrm{dd}, J=2.4 \mathrm{~Hz}, J=0.9 \mathrm{~Hz}, 1 \mathrm{H}, 3^{\prime}-\mathrm{H}\right), 6.24$ (d, $J=$ $9.8 \mathrm{~Hz}, 1 \mathrm{H}, 3-\mathrm{H}), 5.52(\mathrm{dd}, J=7.2 \mathrm{~Hz}, J=1.4 \mathrm{~Hz}$, $1 \mathrm{H}, 3$ "-H), 4.90 (d, $J=7.0 \mathrm{~Hz}, 2 \mathrm{H}, 2$ "-H), 1.79 (d, $J=0.9 \mathrm{~Hz}, 3 \mathrm{H}, 4$ "-H), 1.69 (d, $J=0.9 \mathrm{~Hz}, 3 \mathrm{H}, 5$ "$\mathrm{H}) .-{ }^{13} \mathrm{C}\left\{{ }^{1} \mathrm{H}\right\}$ NMR: $\delta=161.28(\mathrm{C}-2), 105.08$ (C3), 139.63 (C-4), 139.76 (C-5), 158.04 (C-6), 114.04 (C-7), 94.10 (C-8), 152.54 (C-9), 107.35 (C-10), 144.88 (C-2'), 112.45 (C-3’), 69.62 (C-2”), 119.01 (C-3"), 139.76 (C-6"), 25.76 (C-4"), 18.17 (C-5").

Oxypeucedanin $\left(\mathrm{C}_{16} \mathrm{H}_{14} \mathrm{O}_{5}, M_{\mathrm{r}} 286\right):{ }^{1} \mathrm{H}$ NMR $\left(\mathrm{CDCl}_{3}\right): \delta=8.21$ [dd, $J=9.8 \mathrm{~Hz}, J=0.6 \mathrm{~Hz}$ (long range), $1 \mathrm{H}, 4-\mathrm{H}], 7.62\left(\mathrm{~d}, J=2.4 \mathrm{~Hz}, 1 \mathrm{H}, 2^{\prime}-\mathrm{H}\right)$, $7.20(\mathrm{dd}, J=0.8 \mathrm{~Hz}, J=0.9 \mathrm{~Hz}, 1 \mathrm{H}, 8-\mathrm{H}), 6.95$ $\left(\mathrm{dd}, J=2.4 \mathrm{~Hz}, J=0.9 \mathrm{~Hz}, 1 \mathrm{H}, 3^{\prime}-\mathrm{H}\right), 6.32$ (d, $J=$ $9.8 \mathrm{~Hz}, 1 \mathrm{H}, 3-\mathrm{H}), 4.60(\mathrm{dd}, J=10.8 \mathrm{~Hz}, J=4.4 \mathrm{~Hz}$, $1 \mathrm{H}, 2$ "-H), 4.45 (dd, $J=10.8 \mathrm{~Hz}, J=4.4 \mathrm{~Hz}, 1 \mathrm{H}$, 2"-H), 3.23 (dd, $J=4.4 \mathrm{~Hz}, J=6.5 \mathrm{~Hz}, 1 \mathrm{H}, 3$ "-H), 1.41 (s, 3H, 4"-H) and 1.33 (s, 3H, 5"-H).

Prangenin $\left(\mathrm{C}_{16} \mathrm{H}_{14} \mathrm{O}_{5}, \quad M_{\mathrm{r}} \quad 286\right):{ }^{1} \mathrm{H} \quad$ NMR $\left(\mathrm{CDCl}_{3}\right): \delta=7.77(\mathrm{~d}, J=9.6 \mathrm{~Hz}, 1 \mathrm{H}, 4-\mathrm{H}), 7.70$ $\left(\mathrm{d}, J=2.2 \mathrm{~Hz}, 1 \mathrm{H}, 2^{\prime}-\mathrm{H}\right), 7.40(\mathrm{~s}, 1 \mathrm{H}, 5-\mathrm{H}), 6.83$ $\left(\mathrm{d}, J=2.2 \mathrm{~Hz}, 1 \mathrm{H}, 3^{\prime}-\mathrm{H}\right), 6.38(\mathrm{~d}, J=9.6 \mathrm{~Hz}, 1 \mathrm{H}$, $3-\mathrm{H}), 4.60(\mathrm{dd}, J=14 \mathrm{~Hz}, J=4.5 \mathrm{~Hz}, 1 \mathrm{H}, 2$ - $-\mathrm{H})$, 4.58 (dd, $J=14 \mathrm{~Hz}, J=4.5 \mathrm{~Hz}, 1 \mathrm{H}, 2$ "-H), 3.32 $(\mathrm{dd}, J=4.4 \mathrm{~Hz}, J=6.5 \mathrm{~Hz}, 1 \mathrm{H}, 3$ "'-H), 1.35 (s, 3H, $4 "-\mathrm{H})$ and 1.28 (s, 3H, 5"-H).

The second most abundant furanocoumarin, having a slightly higher retention time than imperatorin in the HPLC analysis, could not be identified with certainty (6 in Fig. 2). Its UV spectrum was identical with that published for isopimpinellin and phellopterin (Lee and Soine, 1969).
Comparison with a chromatogram in a published study using a similar HPLC system (Waksmundzka-Hajnos et al., 2004) showed that the relative retention time makes it highly unlikely that the unidentified compound was isopimpinellin, the retention time of which would be expected between those of xanthotoxin and bergapten (as is the case for unidentified 1 in Fig. 2). Finally, as phellopterin is usually a prominent compound in A. archangelica fruit (Murray et al., 1982), and not accounted for elsewhere in this analysis, the unidentified compound was assumed to be phellopterin.

Prangenin had been isolated and identified by NMR spectroscopy but could not be measured accurately by HPLC, as an unidentified furanocoumarin with a different UV spectrum had the same retention time. This unidentified compound was probably isopimpinellin, based on (i) its UV spectrum (results not shown), (ii) the fact that it has been detected by GC-MS in many samples of Icelandic $A$. archangelica fruit (results not shown), and (iii) its retention time relative to xanthotoxin and bergapten published in the previously mentioned study (Waksmundzka-Hajnos et al., 2004). In the quantitative analysis, prangenin and this unidentified compound were taken together and called "unidentified 1 ".

A furanocoumarin with a retention time between oxypeucedanin and imperatorin could not be indentified, and was referred to as "unidentified 2" in this study. It is probably 8-substituted, with a UV spectrum similar to those of xanthotoxin and imperatorin (results not shown).

\section{Results}

The main results are taken together in Tables I and II. As seen in Table I, the average of the total furanocoumarin quantity was $22.5 \mathrm{mg} / \mathrm{g}$ ranging from 14.0 to $31.6 \mathrm{mg} / \mathrm{g}$. In all cases, imperatorin was by far the most prominent compound of this class in the fruits, $33.9-58.2 \%$. Apart from imperatorin, the order of the quantity was variable. The assumed phellopterin accounted for $6.1-23.8 \%$, isoimperatorin for $2.0-25.0 \%$, oxypeucedanin for $0-21.8 \%$, bergapten for $3.3-13.3 \%$, xanthotoxin for $2.9-14.7 \%$, and unidentified 2 for $0-8.6 \%$.

The main differences in composition were related to oxypeucedanin and unidentified 2 which could not be detected in 7 samples from South Iceland. 
Table I. Furanocoumarin content $(\mathrm{mg} / \mathrm{g})$ in $A$. archangelica fruits from Iceland. The average content and the range (minimum and maximum) of each compound are given.

\begin{tabular}{lccc}
\hline Furanocoumarin & \multicolumn{3}{c}{ Content $(\mathrm{mg} / \mathrm{g})$} \\
\cline { 2 - 4 } & Average & Minimum & Maximum \\
\hline Xanthotoxin & 1.59 & 0.59 & 3.58 \\
Unidentified 1 & 0.55 & 0.17 & 1.78 \\
Bergapten & 1.88 & 0.61 & 3.96 \\
Oxypeucedanin & 2.04 & 0.00 & 6.45 \\
Unidentified 2 & 0.43 & 0.00 & 1.64 \\
Imperatorin & 10.35 & 5.82 & 15.55 \\
Phellopterin & 3.26 & 1.13 & 7.50 \\
Isoimperatorin & 2.36 & 0.34 & 6.17 \\
Total & 22.47 & 13.95 & 31.62 \\
\hline
\end{tabular}

Table II. Furanocoumarin composition (\%) in A. archangelica fruits from Iceland. The average ratio and the range (minimum and maximum) of each compound are given.

\begin{tabular}{lccc}
\hline Furanocoumarin & \multicolumn{3}{c}{ Content (\%) } \\
\cline { 2 - 4 } & Average & Minimum & Maximum \\
\hline Xanthotoxin & 7.2 & 2.9 & 14.7 \\
Unidentified 1 & 2.5 & 0.7 & 8.9 \\
Bergapten & 8.3 & 3.3 & 13.3 \\
Oxypeucedanin & 9.0 & 0.0 & 21.8 \\
Unidentified 2 & 2.1 & 0.0 & 8.6 \\
Imperatorin & 46.5 & 33.9 & 58.2 \\
Phellopterin & 14.3 & 6.1 & 23.8 \\
Isoimperatorin & 10.4 & 2.0 & 25.0 \\
\hline
\end{tabular}

No generalizations could be made on the furanocoumarin compositions with regard to location, as considerable differences in composition were often found between samples from neighbouring locations. However, when the data was taken together, geographical impact was found on the furanocoumarin composition. Samples with high percentage of isoimperatorin and those with high percentage of bergapten were more likely to be found in South Iceland than in North Iceland (Figs. 3 and 4), whereas the opposite was true for oxypeucedanin and unidentified 2 (Figs. 5 and 6). Locations more abundant in xanthotoxin (Fig. 7) were distributed similarly to those high in bergapten, although xanthotoxin was more likely to be prominent in West Iceland whereas bergapten was more abundant in East Iceland. No geographical pattern was found in the distribution of locations with high abundance of imperatorin and assumed phellopterin.

A small-scale experiment was carried out to estimate the relative contributions of environmen-

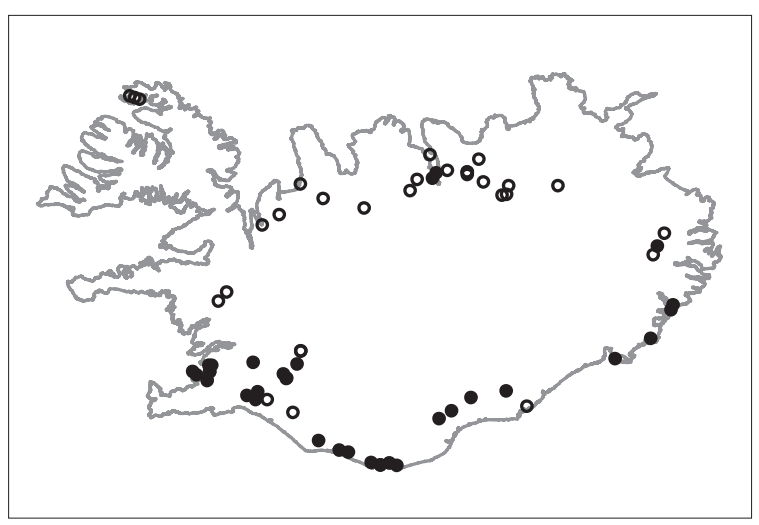

Fig. 3. Locations with isoimperatorin representing more than the average percentage $(10.4 \%)$ of the total furanocoumarin content are shown with filled circles and locations with less than the average are shown with open circles.

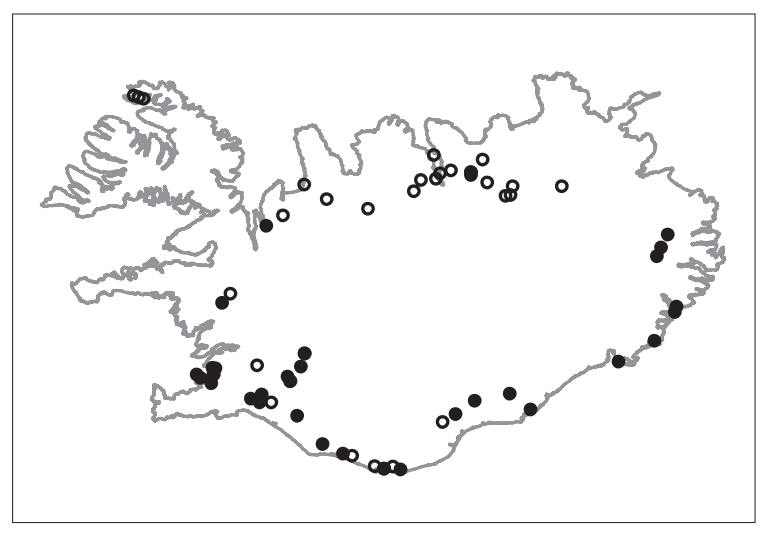

Fig. 4. Locations with bergapten representing more than the average percentage $(8.3 \%)$ of the total furanocoumarin content are shown with filled circles and locations with less than the average are shown with open circles.

tal factors and individual genetic make-up. Fruits from 4 individual plants (A-D) growing within $5 \mathrm{~m}$ of each other in Southwest Iceland were collected, extracted, and analysed as described above, albeit in monoplicate. The results (Table III) reveal a highly diverse composition, individual A containing a lower percentage of xanthotoxin and assumed phellopterin than any pooled sample (1.6 and $4.6 \%$, respectively), whereas the xanthotoxin percentage of individual $\mathrm{D}$ was at the opposite extreme with $14.5 \%$. The imperatorin percentage of the individual plants ranged from $37.6 \%$ to $56.5 \%$. And, finally, individual D 


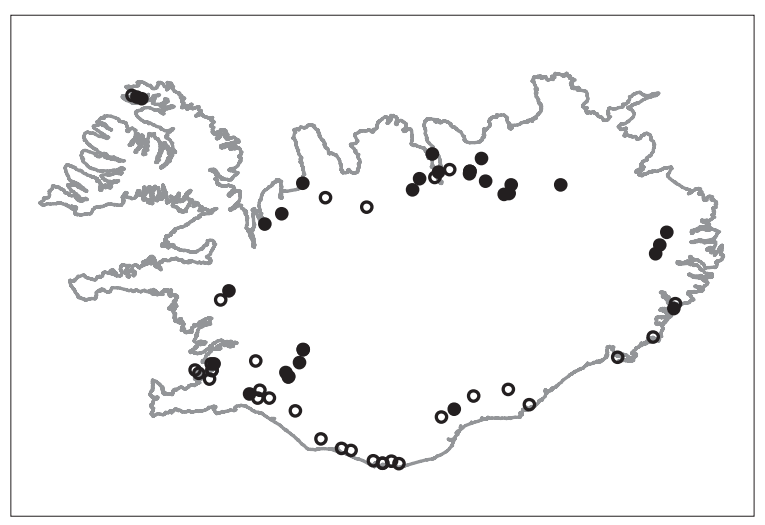

Fig. 5. Locations with oxypeucedanin representing more than the average percentage $(9.0 \%)$ of the total furanocoumarin content are shown with filled circles and locations with less than the average are shown with open circles.

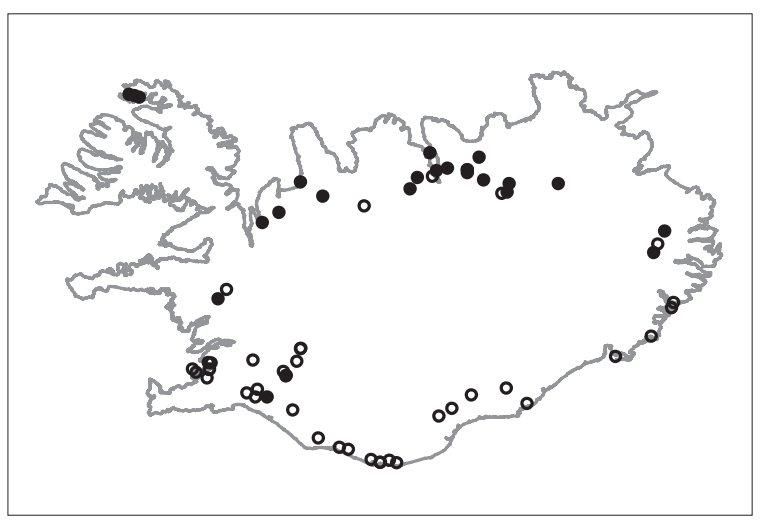

Fig. 6. Locations with "unidentified 2" representing more than the average percentage $(2.1 \%)$ of the total furanocoumarin content are shown with filled circles and locations with less than the average are shown with open circles.

had no detectable oxypeucedanin or unidentified 2, as was the case for 7 pooled samples from South Iceland.

\section{Discussion}

The furanocoumarin composition of Icelandic $A$. archangelica fruits is more or less similar, containing the same compounds in varying contents, and imperatorin being most abundant in all samples.

Besides xanthotoxin, bergapten, oxypeucedanin, imperatorin, and isoimperatorin, which could be identified with standards or purified compounds, the samples analysed by HPLC also

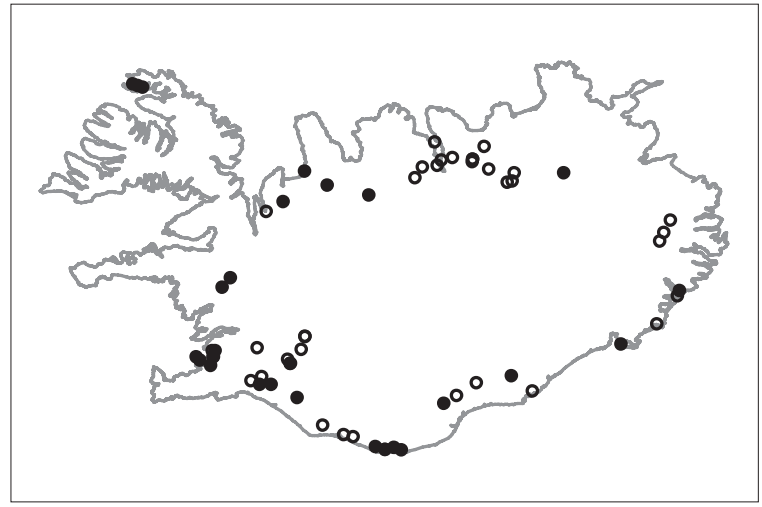

Fig. 7. Locations with xanthotoxin representing more than the average percentage $(7.2 \%)$ of the total furanocoumarin content are shown with filled circles and locations with less than the average are shown with open circles.

Table III. Furanocoumarin content $(\mathrm{mg} / \mathrm{g})$ in $A$. archangelica fruits from individual plants A, B, C, and D.

\begin{tabular}{lrrrr}
\hline Furanocoumarin & \multicolumn{4}{c}{ Content $(\mathrm{mg} / \mathrm{g})$} \\
\cline { 2 - 5 } & $\mathrm{A}$ & $\mathrm{B}$ & $\mathrm{C}$ & $\mathrm{D}$ \\
\hline Xanthotoxin & 0.4 & 1.0 & 1.1 & 2.0 \\
Unidentified 1 & 0.4 & 1.1 & 0.4 & 0.1 \\
Bergapten & 3.9 & 1.3 & 2.1 & 1.5 \\
Oxypeucedanin & 2.6 & 1.5 & 1.2 & 0.0 \\
Unidentified 2 & 0.8 & 0.1 & 0.8 & 0.0 \\
Imperatorin & 14.4 & 5.6 & 11.1 & 7.8 \\
Phellopterin & 1.2 & 2.5 & 2.5 & 1.2 \\
Isoimperatorin & 2.1 & 1.8 & 0.7 & 1.2 \\
\hline Total & 25.8 & 14.9 & 19.9 & 13.8 \\
\hline
\end{tabular}

contained furanocoumarins which could not be identified with certainty. The most abundant of those compounds was assumed to be phellopterin for reasons given above. The second most abundant of those compounds, unidentified 2, has a UV spectrum similar to those of xanthotoxin and imperatorin. Additionally, prangenin could not be quantified, due to an unidentified compound, possibly isopimpinellin, having the same retention time in the HPLC analysis.

The differences in composition relate mainly to oxypeucedanin and unidentified 2, which are totally absent in some locations in South Iceland but account for more than $8 \%$ each in other locations (in North Iceland).

Samples with a high proportion of isoimperatorin and bergapten were much more likely to be found in South Iceland than in North Iceland, 
while the opposite was true for oxypeucedanin and unidentified 2. Samples with a high proportion of xanthotoxin were more likely to occur in the western half of Iceland.

When fruits from individual plants were analysed separately, more differences were seen. The four individuals from the same location, growing within meters of each other, showed great variation in furanocoumarin quantity and composition, respectively. One individual was devoid of oxypeucedanin and unidentified 2, like seven samples from South Iceland, one contained very little xanthotoxin and assumed phellopterin but much imperatorin. This indicates genetic control of quantity and composition of furanocoumarins and makes the idea of culturing or cloning individuals with desirable properties, such as high

Abad M. J., de las Heras B., Silván A. M., Pascual R., Bermejo P., Rodriquez B., and Villar A. M. (2001), Effects of furocoumarins from Cachrys trifida on some macrophage functions. J. Pharm. Pharmacol. 53, 1163-1168.

Appendino G., Bianchi F., Bader A., Campagnuolo C., Fattorusso E., Taglialatela-Scafati O., Blanco-Molina M., Macho A., Fiebich B. L., Bremner P., Heinrich M., Ballero M., and Muñoz E. (2004), Coumarins from Opopanax chironium. New dihydrofuranocoumarins and differential induction of apoptosis by imperatorin and heraclenin. J. Nat. Prod. 67, 532-536.

Ban H. S., Lim S. S., Suzuki K., Jung S. H., Lee S., Lee Y. S., Shin K. H., and Ohuchi K. (2003), Inhibitory effects of furanocoumarins isolated from the roots of Angelica dahurica on prostaglandin E2 production. Planta Med. 69, 408-412.

Chiou W. F., Huang Y. L., Chen C. F., and Chen C. C. (2001), Vasorelaxing effect of coumarins from Cnidium monnieri on rabbit corpus cavernosum. Planta Med. 67, 282-284.

Choi S. Y., Ahn E. M., Song M. C., Kim D. W., Kang J. H., Kwon O. S., Kang T. C., and Baek N. I. (2005), In vitro GABA-transaminase inhibitory compounds from the root of Angelica dahurica. Phytother. Res. 19, 839-845.

Di Giovanni S., Borloz A., Urbain A., Marston A., Hostettmann K., Carrupt P. A., and Reist M. (2008), In vitro screening assays to identify natural or synthetic acetylcholinesterase inhibitors: thin layer chromatography versus microplate methods. Eur. J. Pharm. Sci. 33, 109-119.

He J. Y., Zhang W., He L. C., and Cao Y. X. (2007), Imperatorin induces vasodilatation possibly via inhibiting voltage dependent calcium channel and receptor- furanocoumarin content or high imperatorin content, feasible.

Taken together, the present results indicate some geographical impact on the furanocoumarin composition of Icelandic $A$. archangelica fruits, and that genetical factors may contribute significantly to the relative quantity of individual components. The results further demonstrate the importance of the analysis of plant material, as material from the same species can be highly diverse in its secondary metabolite composition.

\section{Acknowledgements}

This study was supported by the Icelandic Research Fund (Division of Science and Innovation) and the Icelandic Ministry of Industry Energy and Tourism.

mediated $\mathrm{Ca}^{2+}$ influx and release. Eur. J. Pharmacol. 573, 170-175.

Ivey F. D., Wang L., Demirbas D., Allain C., and Hoffman C. S. (2008), Development of a fission yeast-based high-throughput screen to identify chemical regulators of cAMP phosphodiesterases. J. Biomol. Screen. 13, $62-71$.

Kawaii S., Tomono Y., Ogawa K., Sugiura M., Yano M., Yoshizawa Y., Ito C., and Furukawa H. (2001), Antiproliferative effect of isopentenylated coumarins on several cancer cell lines. Anticancer Res. 21, $1905-1911$.

Kim D. K., Lim J. P., Yang J. H., Eom D. O., Eun J. S., and Leem K. H. (2002), Acetylcholinesterase inhibitors from the roots of Angelica dahurica. Arch. Pharm. Res. 25, 856-859.

Kleiner H. E., Xia X., Sonoda J., Zhang J., Pontius E., Abey J., Evans R. M., Moore D. D., and DiGiovanni J. (2008), Effects of naturally occurring coumarins on hepatic drug-metabolizing enzymes in mice. Toxicol. Appl. Pharmacol. 232, 337-350.

Lee K. H. and Soine T. O. (1969), X. Spectral studies on some linear furanocoumarins. J. Pharm. Sci. 58, $681-683$.

Löve Á. (1977), Íslenzk ferðaflóra (The Icelandic Flora for Travelers). Almenna bókafélagið, Reykjavík.

Murray R. D. H., Mendez J., and Brown S. A. (1982), The Natural Coumarins. Occurrence, Chemistry and Biochemistry. John Wiley \& Sons, Chichester.

Newall C. A., Andersen L. A., and Phillipson J. D. (1996), Herbal Medicines. A Guide for Health Care Professionals. The Pharmaceutical Press, London.

Pae H.-O., Oh H., Yun Y.-G., Oh G.-S., Jang S., Hwang K.-M., Kwon T.-O., Lee H.-S., and Chung H.-T. (2002), Imperatorin, a furanocoumarin from $A n$ gelica dahurica (Umbelliferae), induces cytochrome 
c-dependent apoptosis in human promyelocytic leukaemia, HL-60 cells. Pharmacol. Toxicol. 91, 40-48.

Sigurdsson S., Ogmundsdottir H. M., and Gudbjarnason S. (2004), Antiproliferative effect of Angelica archangelica fruits. Z. Naturforsch. 59c, 523-527.

Waksmundzka-Hajnos M., Petruczynik A., Dragan A., Wianowska D., Dawidowicz A. L., and Sowa I. (2004), Influence of the extraction mode on the yield of some furanocoumarins from Pastinaca sativa fruits. J. Chromatogr. B: Anal. Technol. Biomed. Life Sci. 800, $181-187$.
Wang C. C., Chen L. G., and Yang L. L. (1999), Inducible nitric oxide synthase inhibitor of the Chinese herb I. Saposhnikovia divaricata (Turcz.) Schischk. Cancer Lett. 145, 151-157.

Wang S. J., Lin T. Y., Lu C. W., and Huang W. J. (2008), Osthole and imperatorin, the active constituents of Cnidium monnieri (L.) Cusson, facilitate glutamate release from rat hippocampal nerve terminals. Neurochem. Int. 53, 416-423. 